\title{
Data base of Chornobyl radioactive waste localised in Ukraine, Belarus and Russia
}

\author{
E. Sobotovich, V. Skvortsov, N. Golovko and Ch. Brun-Yaba ${ }^{1}$
}

\author{
State Scientific Centre for Environmental Radiogeochemistry of National Academy of Sciences, \\ Paladin Av. 34a, Kiev 252142, Ukraine \\ ${ }^{1}$ Institute for Nuclear Safety and Protection (IPSN), Department of Environmental Protection \\ (DPRE), CEA FAR, BP. 6, 92265 Fontenay-aux-Roses cedex, France
}

\begin{abstract}
Various materials and substations containing ${ }^{137} \mathrm{Cs}$, ${ }^{90} \mathrm{Sr}$, transuraniums and others radionuclides had been assembled during decontamination of Ukrainian, Belarussian and Russian territories polluted in consequence of Chernobyl Catastrophe. They have been localised in numerous disposal sites as radioactive waste (RW). The overwhelming majority of disposal sites do not meet the requirements of safety. The researches aiming development of the RW management strategy are carried out within the framework of the project "Franco-German Initiative for Chernobyl". The participants of the project are IPSN (France), GRS (German), SSCER (Ukraine), Comchernobyl (Belarus), and IBRAE (Russia).

A database creation has been one of the main tasks. The database contains practically whole information on the localised RW. The data analyses have been resulted in categorisation of the RW and a categorisation of the disposal sites. There have been detected effects of RW influence on an environment: dependence of effective radiation doze rate over disposal sites on RW specific activity; increasing the dose rate over periodically flooded disposal sites; seasonal fluctuations of radionuclides concentration in ground water near disposal sites without engineering barriers.

Analysis of the database has shown that further progress requires improvements of methodology and technology of the RW disposal sites survey.
\end{abstract}

\section{History of the Chernobyl waste dumps and trenches}

The Chernobyl accident that was being caused by explosion of the Chernobyl Nuclear Power Plant 4-th power unit (Ukraine) in April 261986 has resulted in occurrence of huge masses of radioactive waste. Radioactive waste of Chernobyl origin (herein referred to as Chernobyl RW) are materials and substations containing radio-nuclides - components of fuel and products of nuclear reactions of destroyed ChNPP 4-th power unit, in concentration or activity exceeding levels of decontrol and use of which is not provided. Radiaocative waste of highest activity levels (so-called fuel containing masses, debris of the build, fuel dust, etc.) are in destroyed power unit ("Shelter" object) and within adjoining so-called technological layer. The numerous fragments of walls, roof and frames of the power unit building, fragments of the reactor active zone, radioactive dust have been thrown out by explosion on adjoining territory in radius of some kilometres. The extensive territories of Ukraine, Belarus and Russia have been polluted by nuclear fall-out.

Most polluted territory near destroyed power unit was being de-contaminated in 1996-97. Other territories had been de-contaminated during next years. In result large volumes of radioactive materials and substations classified as RW have been assembled. The Chernobyl RW are rather various by kinds of materials, activity, and proportion of separate radionuclides activity. They represent the polluted ground, wood, elements of ironworks, ferro-concrete blocks, equipment, mechanisms, etc. The significant part of $\mathrm{RW}$ contains fragments of nuclear fuel and reactor graphite. Main RW radionuclides are ${ }^{137} \mathrm{Cs},{ }^{90} \mathrm{Sr}$, transuraniums ${ }^{239} \mathrm{Pu},{ }^{240} \mathrm{Pu},{ }^{241} \mathrm{Am}$ and others. These $\mathrm{RW}$ have been localised into numerous disposal sites in Ukraine within Chernobyl Exclusion Zone and also in Belarus and Russia. The overwhelming majority of disposal sites represents simple trenches or clamps without any barriers. In Ukraine such disposal sites are more than 1000, in Belarus, 92 and in Russia 19. Only few several disposal sites containing RW of high activity have barriers, but not nearly each of them meets the requirements of the safety.

De-contamination of territory and localisation of RW were carried out in extremely dangerous radiological conditions. The disposal sites were created without the official documentation and any authentic data on disposal sites and RW characteristics are absent. The available data are especially expert ratings, which have been received as a result of disposal sites inspection by indirect methods since 1990 . 
A line of researches purposing finding-out a potential ecological danger of the localised RW and development of counter-measures was being carried out in the beginning of $90-\mathrm{s}$. The most important results were being achieved within the framework of the project TACIS UR/029 in 1995 [1]. New data on localised RW that were being received as a result of their inventory in last years enable to more authentically estimates the potential danger of the localised RW. With this purpose researches "Waste Dumps and Waste Strategies Management" are carried out now within the framework of the project "Radio-ecological Consequences of the Chernobyl Accident", which is a part of the general project "Franco-German Initiative for Chernobyl". The latter is carried out by IPSN (France), GRS (German), SSCER (Ukraine), Comchernobyl (Belarus), IBRAE (Russia) and others scientific and industrial organisations.

\section{Creation of the waste database REDAC}

The creation of a database is one of the main research problems. During the database creation have been developed categorisation of the localised RW and categorisation of the disposal sites. The database has been analysed with the purpose of detection of effects of the localised RW influence on an environment. The task of the Project final stage is choice of best strategic decisions and preventing a RAW influence on the surround ambience with least expenses. The results of researches that had been executed are briefly stated in this paper. The developed database is intended for input, storage, editing, and analysis of information on disposal sites and conditions of Ukrainian, Russian and Belorussian RW. The Database provides a work in Russian and English languages. The information is represented by appropriate pages of a database (examples are represented by fig. 2 ).

"General data" - the information on disposal site name, standing, category, current status, year of a beginning and year of the ending of loading, operating organisation, description of monitoring and physical condition checking control.

"Technical specification" - the information on artificial hydro-isolation of a disposal site and actions on disposal site maintenance.

"Hydrogeological specifications" - data on hydraulic gradient, disposal site depth, ground water depth from disposal site bottom, soil dominating type in a zone of aeration, presence of surface and ground water removing system.

"RW specification" - type, category and amount of RW.

"Measurement" - specific activity of g emitters radionuclides (measured or calculated by regression equations), dose rate in 1 meter over disposal site surface, and adjoining territory contamination
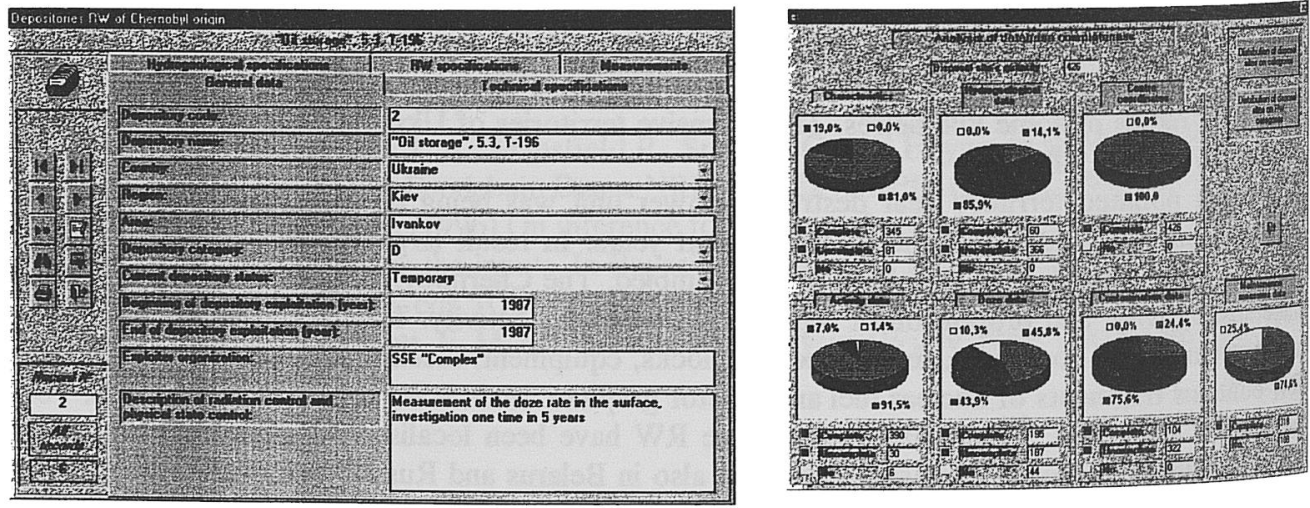

Figure 1: Date Base page examples: a - "Technical specification", b - "Analysis of Data Base completeness"

Chernobyl RW, especially localised in Ukraine, contain transuraniums of various concentration Experimental studies [2] had resulted in radionuclide correlation in RW. This consistent pattern is basis of a technique of RW activity assessment in the disposal sites. Accordingly, the specific activity of ${ }^{90} \mathrm{ST}$, transuraniums, and others radionuclides is defined from the equations of linear regression with using the 
direct data on specific ${ }^{137} \mathrm{Cs}$ activity. The database analysis has shown imperfection of the existing technique, because actually the correlation of radionuclide concentration is non-linear. Latter is probably caused by inconstancy of a correlation with fuel and condensation composings of RW. The development of an adequate technique of the concentration assessment is one of further tasks.

\section{United Categorisation of Chernobyl waste}

Neither in Ukraine, nor Russia and Belarus has got native RW classifications considering specific features of Chernobyl RW, in particular the transuraniums ubiquitous presence. Therefore within the project framework have developed a categorisation of the localised RW. The Categorisation is twodimensional by two criteria - RW specific activity by ${ }^{137} \mathrm{Cs}$ and specific $\alpha$-activity of RW.

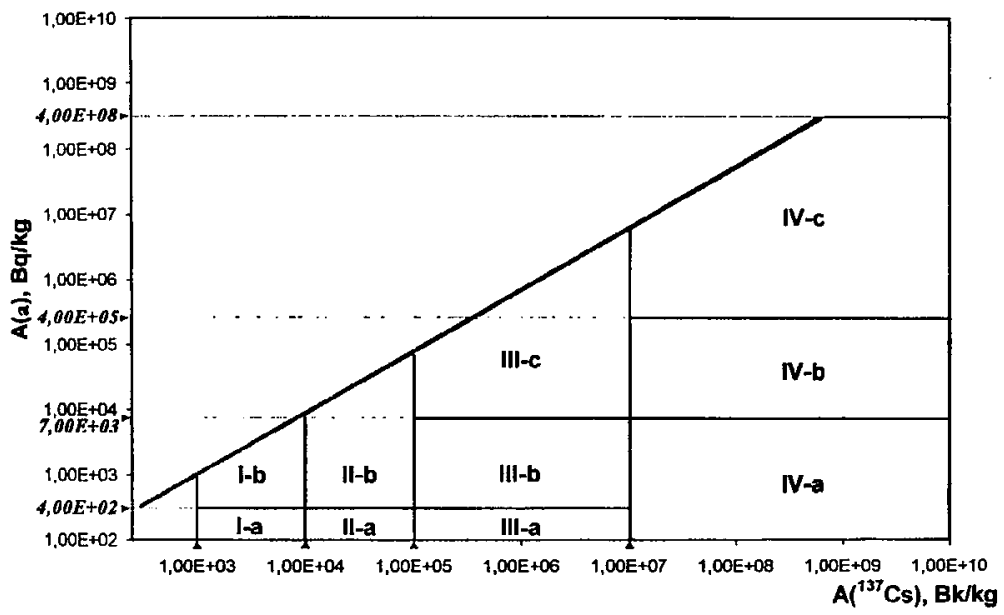

Figure 2: Unified categorisation on RW localised in Belarus, Russia and Ukraine

\section{Unified categorisation on localised RW disposal sites of Belarus, Russia and Ukraine}

The disposal sites categorisation by main technical characteristics causing a level of RW potential danger has been developed also.

\begin{tabular}{|c|l|l|l|l|}
\hline Category & $\begin{array}{c}\text { Type of } \\
\text { disposal site }\end{array}$ & \multicolumn{1}{|c|}{$\begin{array}{c}\text { Basement and wall. } \\
\text { Material }\end{array}$} & \multicolumn{1}{|c|}{$\begin{array}{c}\text { Isolation. } \\
\text { Material }\end{array}$} & \multicolumn{1}{c|}{$\begin{array}{c}\text { RW placement mode and } \\
\text { package }\end{array}$} \\
\hline A & Surface & $\begin{array}{l}\text { Basement and wall. Concrete, } \\
\text { reinforced concrete }\end{array}$ & $\begin{array}{l}\text { Isolation is only } \\
\text { covering. Concrete, } \\
\text { clay }\end{array}$ & $\begin{array}{l}\text { Capacities of reinforced } \\
\text { concrete. Neither packaged nor } \\
\text { non-packaged. }\end{array}$ \\
\hline B & $\begin{array}{l}\text { Near-surface; } \\
\text { of trench type. }\end{array}$ & $\begin{array}{l}\text { Basement and walls. } \\
\text { Concrete, reinforced concrete }\end{array}$ & $\begin{array}{l}\text { Isolation is covering } \\
\text { and littering. Clay }\end{array}$ & $\begin{array}{l}\text { Neither packaged nor non- } \\
\text { packaged. }\end{array}$ \\
\hline C & $\begin{array}{l}\text { Near -surface; } \\
\text { of trench type. }\end{array}$ & Are absent & $\begin{array}{l}\text { Isolation is covering } \\
\text { and littering. Clay }\end{array}$ & Non-packaged \\
\hline D & $\begin{array}{l}\text { Near -surface; } \\
\text { of trench type. }\end{array}$ & Are absent & $\begin{array}{l}\text { Isolation is only } \\
\text { covering. Soil. }\end{array}$ & Non-packaged \\
\hline E & $\begin{array}{l}\text { Near -surface; } \\
\text { of clamp type. }\end{array}$ & Are absent & $\begin{array}{l}\text { Isolation is only } \\
\text { covering. Soil. }\end{array}$ & Non-packaged \\
\hline
\end{tabular}

The data analysis has resulted in discovery of the effects of influence of the localised RW both on a surface radiological situation and on ground waters. 
The data on dose rate have used as information about RW impact on surface radiological situation. The dose rate is conditioned by $\gamma$-radiation. After short-lived radionuclides decay the main source of the $\gamma$-radiation has been arising ${ }^{137} \mathrm{Ba}$ - decay product of ${ }^{137} \mathrm{Cs}$.

It is specified that the disposal sites of different plots as a whole differ by average dose rate values (Fig. 3). It is caused, at least, by two reasons.

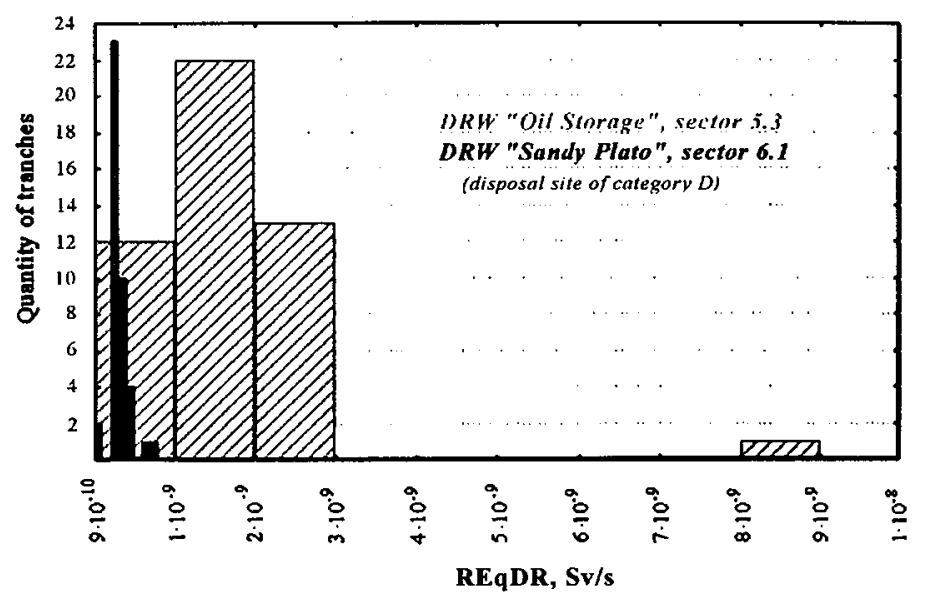

Figure 3: Distribution of Radiation Equivalent Dose Rate values at storage surface

On the one hand a dose Rate depends on RW specific activity of contained in disposal site (fig. 4). Owing to disposal sites cover imperfection, $\gamma$-radiation of radioactive waste penetrates to the surface. It is possible that radioactive waste was not completely covered with «clean» soil or natural processes ruined cover integrity.

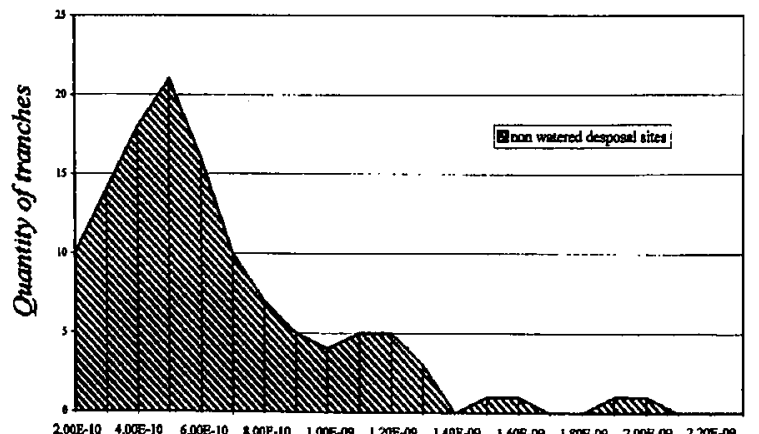

$R E q D R, S v / s$

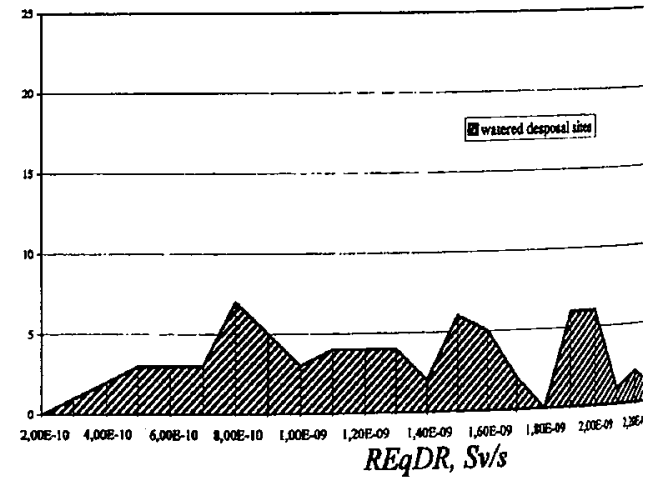

$R E q D R, S v / s$

Figure 4: Distribution of Radiation Equivalent Dose Rate values at the surface of DRW “Oil storage", sector 5/1, disposal site category $\mathbf{D}$

On the other hand, within different areas the ground waters occur at various depths. The sites, where ground waters occur at small depth, are periodically or almost permanently flooded. It promotes radionuclides migration not only into ground water but to the surface as well. In result the dose rate above many flooded disposal sites is much higher, than above others (fig. 5).

Generally, no doubt, that radiological danger of localised RW consists, mainly, in radionuclides contaminating the ground water. However the level of separated disposal sites danger has not been evaluated yet. Stipulation of comparatively high radionuclide concentrations in ground water exactly by the influence of localised RW has not been statistically proved, though high radionuclide concentrations 
in ground water near some disposal site are observed. Existing radionuclides contaminating the ground water is a result of either radionuclide migration from the disposal site or migration from polluted soils through the aeration zone.

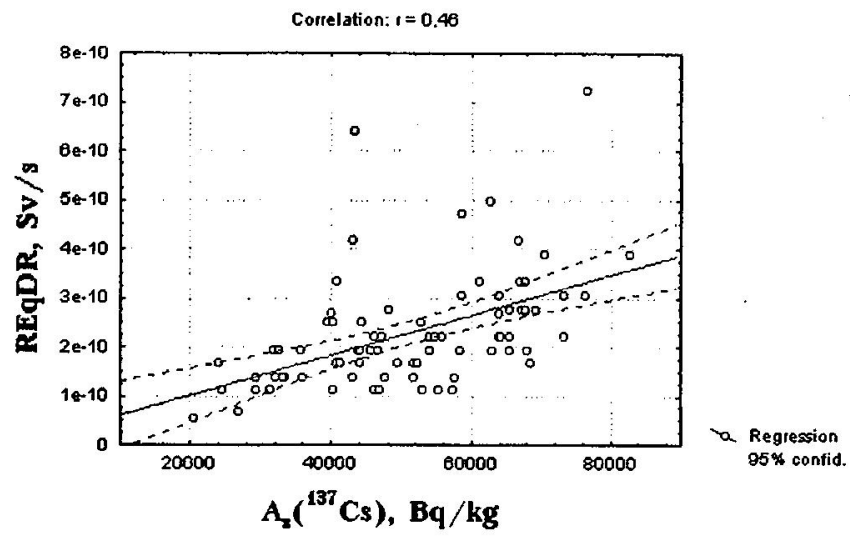

Figure 5: Dependence of Radiation Equivalent Dose Rate on the surface of a disposal site on specific activity of ${ }^{137} \mathrm{Cs}$ in DRW "Sandy Plato" disposal site, sector 6.1, disposal site category D

The radionuclide concentrations in ground water are subject to annual fluctuations with the general trend of increasing, as well as seasonal fluctuations. Seasonal variability of specific activity in ground water has statistically analysed with aim of detecting the effect of localised RW influence on ground water. For this aim there has been used data of monitoring the ground water contamination by ${ }^{90} \mathrm{Sr}$ and ${ }^{137} \mathrm{Cs}$ (2000) from 3 groups of bore holes: I - bore holes within areas of location of disposal sites not having engineering barriers (categories $\mathrm{D}, \mathrm{E}$ ), $\mathrm{II}$ - bore holes within areas of location of disposal sites having engineering barriers (categories A, B, C) and III - bore holes on areas of disposal site absence. There have been analysed statistical distribution of $R=A_{S \max } / A_{S \min }$ parameter, $A_{S_{\max }}$ and $A_{S \min }$ are radionuclides maximum and minimum specific activity, observed in a bore hole during a year (Fig. 6).
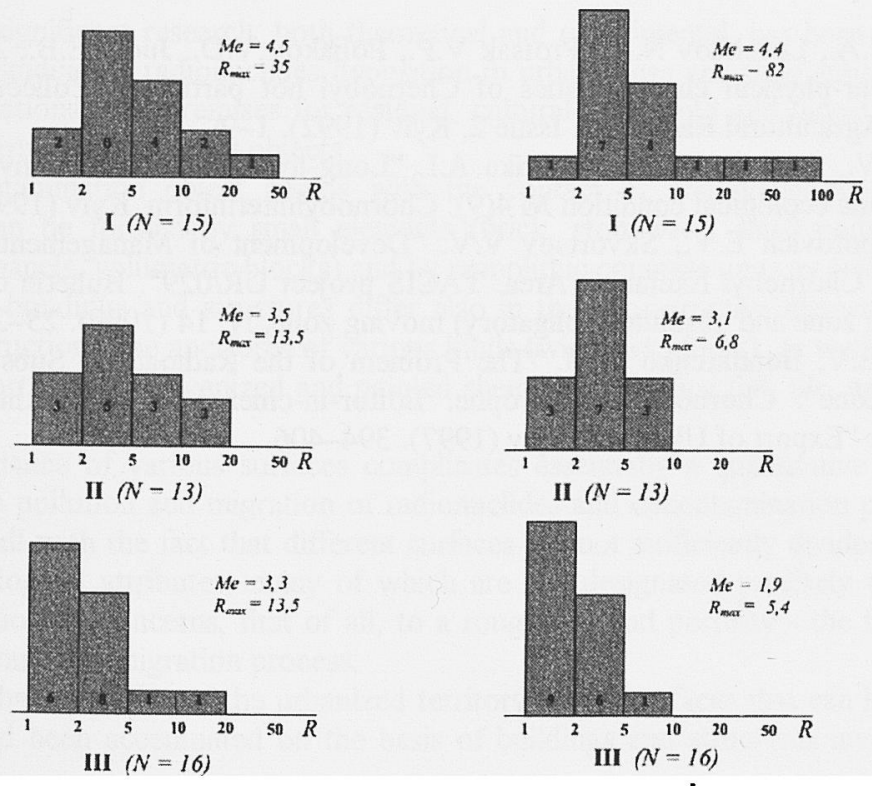

$\boldsymbol{a}$

$b$

Fig 6: Storage influence on season variations of ${ }^{137} \mathrm{Cs}$ (a) and ${ }^{90} \mathrm{Sr}$ (b) specific activity in groundwater Me - median of distribution of $R ; R_{\max }-R$ maximum; I $-R$ distribution on plots within DRW; II $-R$ distribution on plots within SRW; III - $R$ distribution on territory without storages; $N$ - quantity of boreholes within the monitoring net. 
Results of the analysis witness that most specific activity fluctuations are within areas of locations of disposal sites not having engineering barriers and smaller specific activity fluctuations - near disposal sites having engineering barriers. The least specific activity fluctuations represents territories where disposal sites are absent. The results of the statistical analysis are indirect proof of essential rok localised RW in radionuclides contamination of ground water.

In conclusion it needs to emphasise, that problem on estimation of the radiological danger localised Chernobyl RW, regrettably, is distant from the full solving. Results of the studies, which have been executed, as well as recommendations to choosing the technological deciding for minimisation of localised RW danger, which will have been developed till project termination are just next important step in solving the problem. Analysis of the created database containing practically the whole existing information on the localised RW has shown that further progress requires a getting new data by improvements of methodology and technology of the RW disposal sites examination and estimation of their influence on environment.

\section{Acknowledgements}

The authors feel it theirs duty to specialise the participants of the project, due to which the stated resulis were received: from Belarus - G.Anzipov, G.Astashko, S.Kukina, L.Polivko, A.Sushenok, A.Tishune: (Comchernobyl), A.Gvozdev, N.Golikova, V.Skurat (IRP), A.Sonin (MFE); from Russia - R.Bakin, S.Gordeev, V.Kiselev, I.Linge, A.Nikishina, S.Panchenko, A.Shikin (IBRAE); from Ukraine • N.Aleksandrova, A.Rozko, D.Skvortsov (SSCER), V.Antropov, V.Zhilinskiy (SE "Komplex"), S.Kumshaev, N.Kibkalo (AC "Quality"), V.Nagorskiy (SSSPE "Ecocenter").

The authors are also grateful to G. Deville-Cavelin (IPSN) and H. Biesold (GRS) for coordination of project Radioecology and useful discussions.

\section{References}

[1] Kashparov V.A., Loschilov N.A., Protsak V.P., Poljakov V.D., Judin E.B., Zhurba M.A., Parshakov A.E. "Nuclear-physical characteristics of Chernobyl hot particles". Collected papers of Ukraimian Institute of Agricultural Radiology. Issue 2. Kyiv (1992). 1-91.

[2] Zhylinski V.V., Antropov V.M., Habrika A.I. "Long-lived radionuclides inventory". Bulletin on the Exclusion zone ecological condition № 4(9): Chornobylinterinform, Kyiv (1997). 29-35.

[3] Lins V., Sobotovich E.V., Skvortsov V.V. 'Development of Management Strategy for Radwaste Localized in Chornobyl Exclusion Area. TACIS project UR/029". Bulletin of ecological situation in the exclusion zone and absolute (obligatory) moving zone. $N^{\circ} 14$ (1999). 25-261.

[4] Sobotovich E.V, Bondarenko G.M. "The Problem of the Radioactive Substances in the Chornobyl Exclusion Zone". Chornobyl Catastrophe. Editor-in-chief V.G. Baryakhtar. Editorial House of Annual Issue "Export of Ukraine", Kyiv (1997). 394-406. 